\title{
Hydrocarbon Generation Modeling of Abu Gabra Formation in Northern Muglad Basin, Sudan
}

\author{
Mohamed Elfatih Z. Gandol
}

Lecturer at Department of Petroleum Geology, Faculty of Petroleum and Minerals, Al Neelain University, Khartoum-12702, Sudan and PG Scholar at Centre of Exploration Geophysics, Osmania University, Hyderabad-500007, India

\begin{abstract}
Basin modeling has become an important tool in the study of burial history and thermal evaluation of sedimentary basins. Burial history curves of four representative wells in Heglig, Bamboo and Azraq areas have been generated using the modelling software and the burial curves show that the Abu Gabra Formation has entered the oil window during the Early Cretaceous period, at the ages: $133 \mathrm{Ma}, 135 \mathrm{Ma}, 114.7 \mathrm{Ma}$ and 134.5 Ma in Seyal-1, Jamouse NW-1, Bamboo AG-1 and Garad AG-1 wells respectively. The peak of oil generation was reached during the ages between 127 to 111 Ma in Seyal-1, 130 to 125 Ma in Jamouse NW-1 and between 128.3 to $116 \mathrm{Ma}$ in Garad AG-1 well. The 1D models shows that, the oil was expelled from the middle and lower parts of the Abu Gabra Formation in the study area at different ratios whereas the expulsion ratio exceeds $80 \%$ in Seyal-1 well, ranges from 50 to $80 \%$ in Jamouse NW-1 and from 10 to $50 \%$ in Garad AG-1. In Bamboo AG-1 well the $1 D$ model indicates that oil expulsion has not taken place. The models reflect that the oil expulsion decreases from the northward to southern part of the study area and the oil accumulations in Bamboo AG-1 well is non-indigenous, therefore the exploration in some areas of Bamboo field are recommended to review. This research recommends prospective investment on the approved gas accumulations in Heglig field after the reserve estimation and economic studies.
\end{abstract}

Keywords: Muglad, Bamboo, Heglig, Azraq, Abu Gabra Formation, 1D Modelling, Vitrinit Reflectance, Hydrocarbon Generation, Expulsion

\section{Introduction}

The study area (Fig. 1) includes three major oil fields in Sudan namely Heglig, Bamboo and Azraq fields, located in the Muglad basin, south west of Sudan. Muglad basin is a rift basin which extends across the border of the Sudan and the Republic of South Sudan and comprises important oil fields in both countries, whereas the most significant oil discoveries have been made. The study area (Fig. 1) includes three major oil fields in Sudan namely Heglig, Bamboo and Azraq fields, located in the Muglad basin, south west of Sudan. Muglad basin is a rift basin which extends across the border of the Sudan and the Republic of South Sudan and comprises important oil fields in both countries, whereas the most significant oil discoveries have been made.

The main objectives of the present study are to determine the level of thermal maturation, to define the main oil and gas windows and to define the timing of oil and gas generation and expulsion for the three oil fields in the study area based on burial history modeling.

During Aptian-Albian time, the sedimentation was continued in lacustrine and deltaic fan environments resulting in deposition of the Abu Gabra Formation (Fig. 2). Several thousand feet of organic rich lacustrine claystones and shale were deposited with interbedded fine-grained sands and silts. The nature of this deposit was probably the result of a humid climate and lack of external drainage. This unit is estimated to be up to $1830 \mathrm{~m}$ thick and it is the main source rock in the Muglad basin (Schull, 1988).

\section{Methodology}

Modeling of the sedimentary basins has been used by many authors such as Uysal et al., (2000), Rodriguez \& Littke (2001), Sheng \& Middleton (2002), Ershov et al., (2003) and Galushkin et al., (2004).

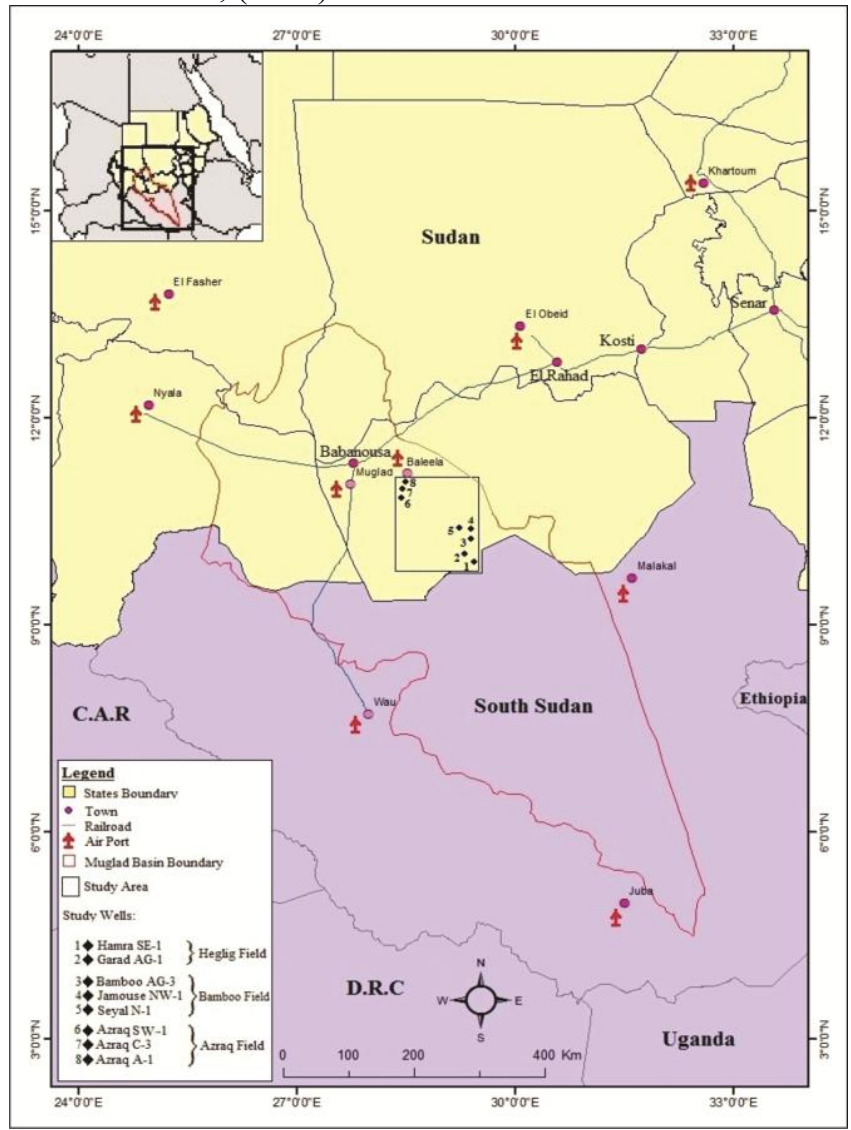

Figure 1: Accessibility and location map of the area of interest 


\section{International Journal of Science and Research (IJSR) \\ ISSN (Online): 2319-7064}

Index Copernicus Value (2013): 6.14 | Impact Factor (2015): 6.391

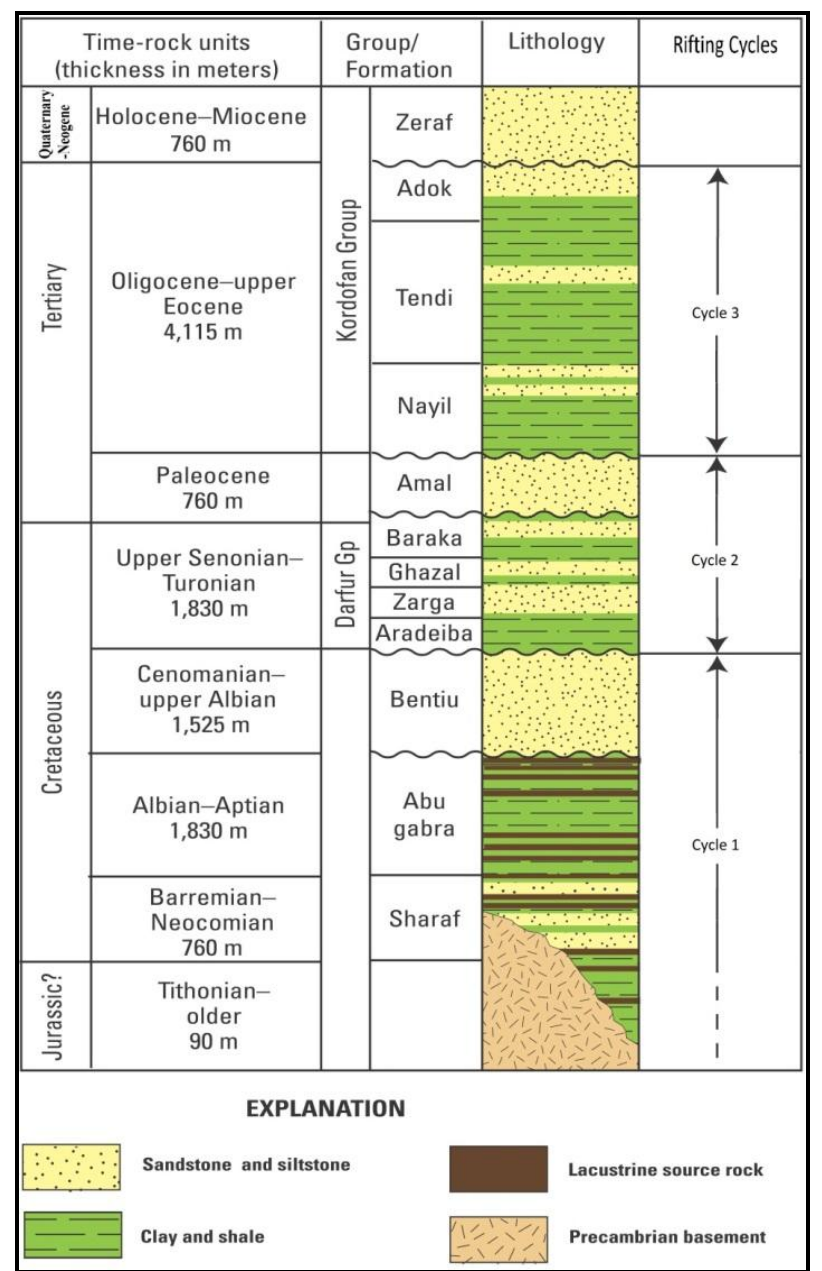

Figure 2: A generalized stratigraphic column of the Muglad basin (modified after Schull, 1988).

The aim of 1D modeling is to determine burial and thermal history of source rock as well as timing of hydrocarbon generation. The essential inputs of maturity modeling is paleo-heat flow that source rock has been subjected to, quantity and quality of organic matter in the sediments (total organic carbon, maturity indicators and hydrogen index) and kinetic equations for the calculation of kerogen conversion to oil and gas (Burnham and Sweeney, 1991). Ibrahim (2012) did a 1D models for two oil wells in Neem and Azraq areas and she suggested two trends of heat flow in the area, high heat flow $(80 \mathrm{~mW} / \mathrm{m} 2)$ in Azraq area and low heat flow $(60 \mathrm{~mW} / \mathrm{m} 2)$ in Neem area.

One-dimensional modeling of burial history and thermal maturity was performed on Seyal-1, Jamouse NW-1, Bamboo AG-1 and Garad AG-1 wells using Genex ${ }^{\circledR}$ (version 4) developed by IFP group. Each model was constructed using stratigraphic thicknesses derived from the composite well logs, lithology (combinations of sandstone, shale, limestone) and absolute ages. In the study area, the calibration data for the thermal models includes vitrinite reflectance and the bottom hole temperature. Modeled vitrinite reflectance has been compared to measured data in order to optimize the thermal history model.

Three rifting phases and varies amount of thinning ( $\beta$ rate) were assumed in this study for the ID modeling (Table.1).
Table 1: Assumed amount of thinning ( $\beta$ rate) of the mantle and the crust for the thermal modeling.

\begin{tabular}{|c|c|c|c|}
\hline Rifting Phase & Period (Ma) & $\beta$ Crust & $\beta$ Mantel \\
\hline First & $150-120$ & 1.5 & 2.0 \\
\hline Second & $77-60$ & 1.1 & 1.5 \\
\hline Third & $33-20$ & 1.0 & 1.5 \\
\hline
\end{tabular}

\section{Results and Discussion}

The calibrated 1D models of the studied wells with real temperature and Vitrinite Reflectance data (Figs. 3 to 10) show that the present day Temperature data and Vitrinite Reflectance measurements are fitting well with the assumed temperature gradient in all of the four 1D thermal models.

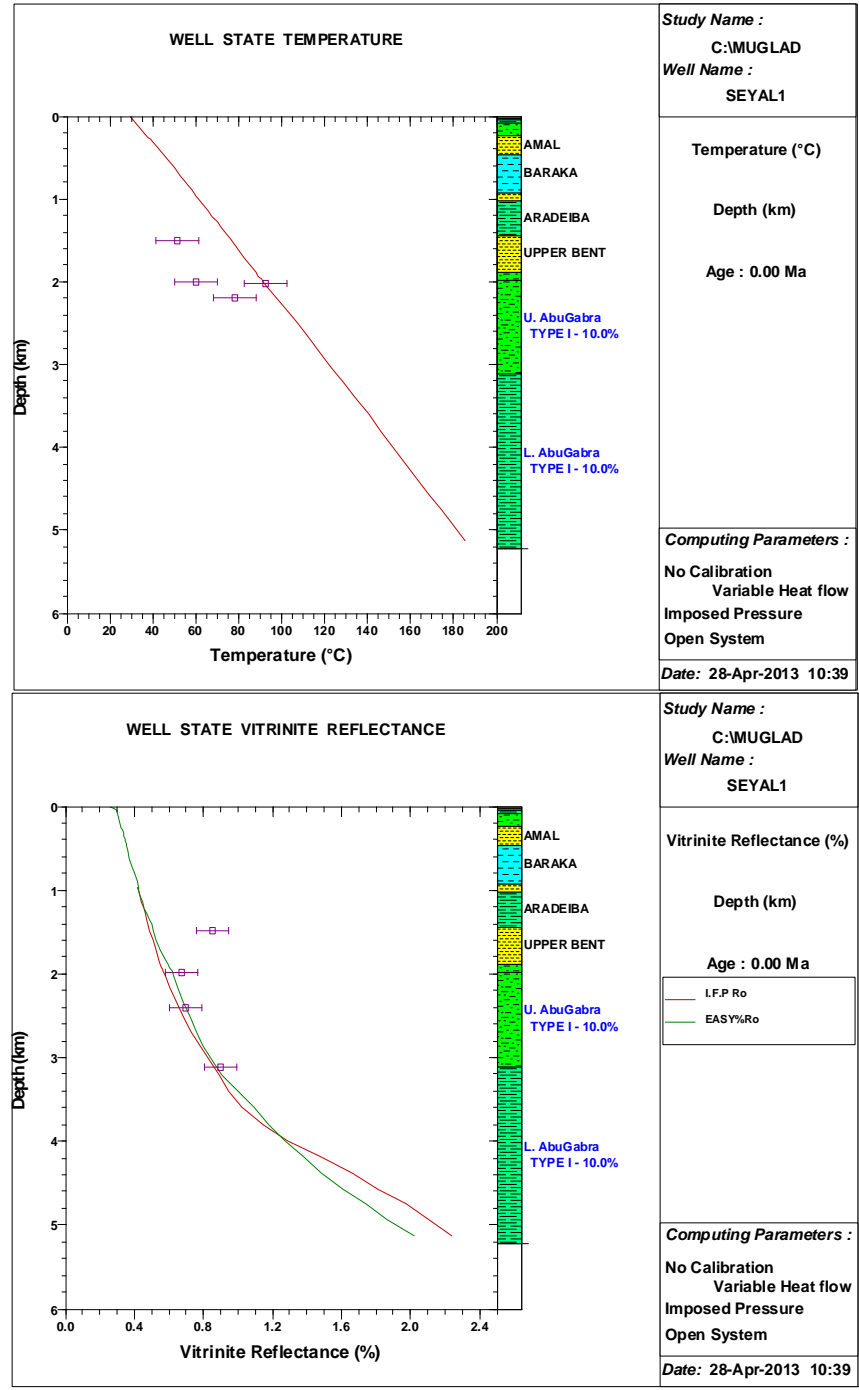

Figures 3 \& 4: Calibrated 1D models for Seyal-1 well with real temperature and Vitrinite Reflectance data. 


\section{International Journal of Science and Research (IJSR) \\ ISSN (Online): 2319-7064}

Index Copernicus Value (2013): 6.14 | Impact Factor (2015): 6.391

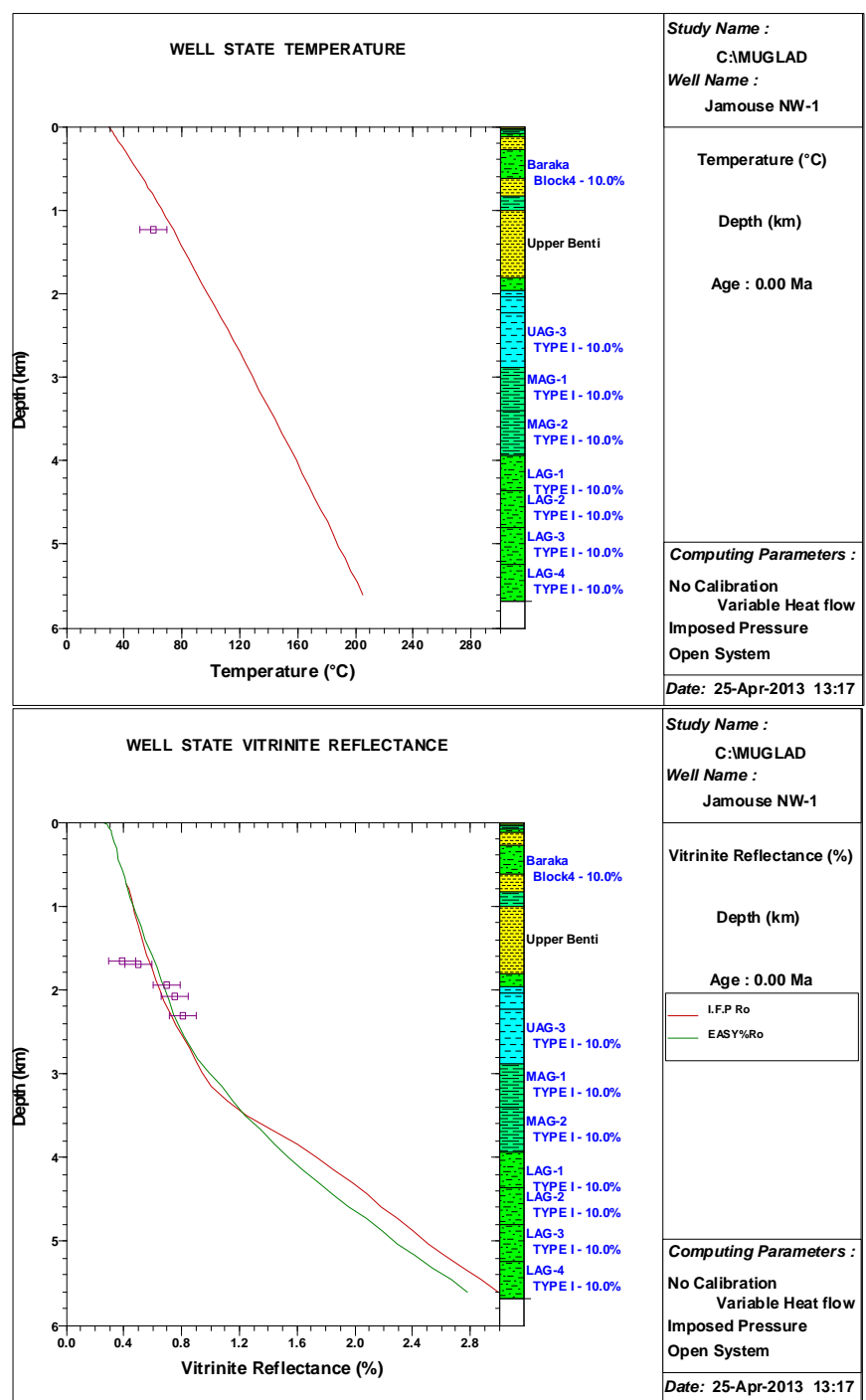

Figures 5 \& 6: Calibrated 1D models for Jamouse NW-1 well with real temperature and Vitrinite Reflectance data.

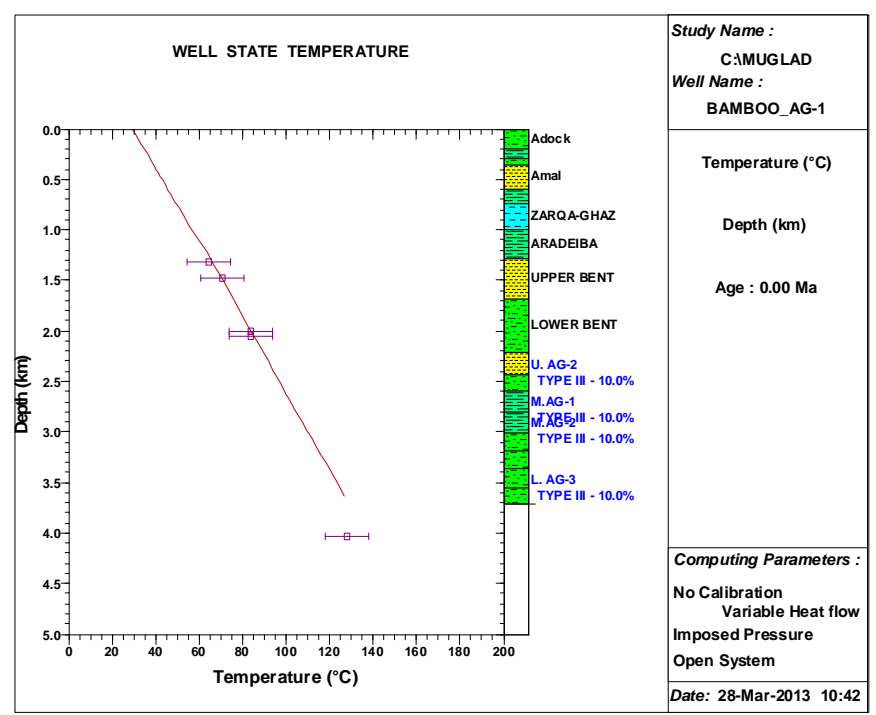

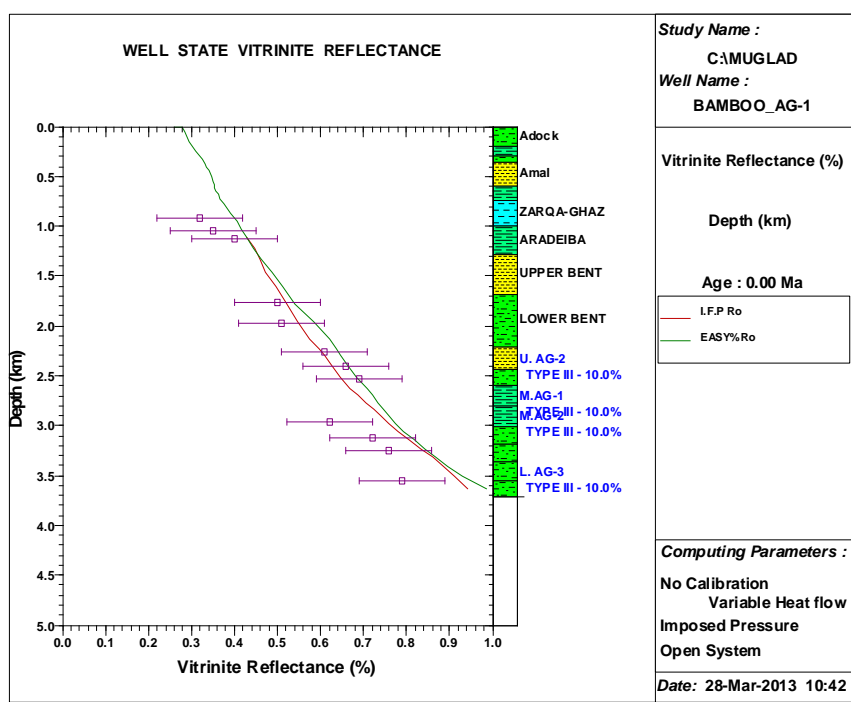

Figures 7 \& 8: Calibrated 1D models for Bamboo AG-1 well with real temperature and Vitrinite Reflectance data.
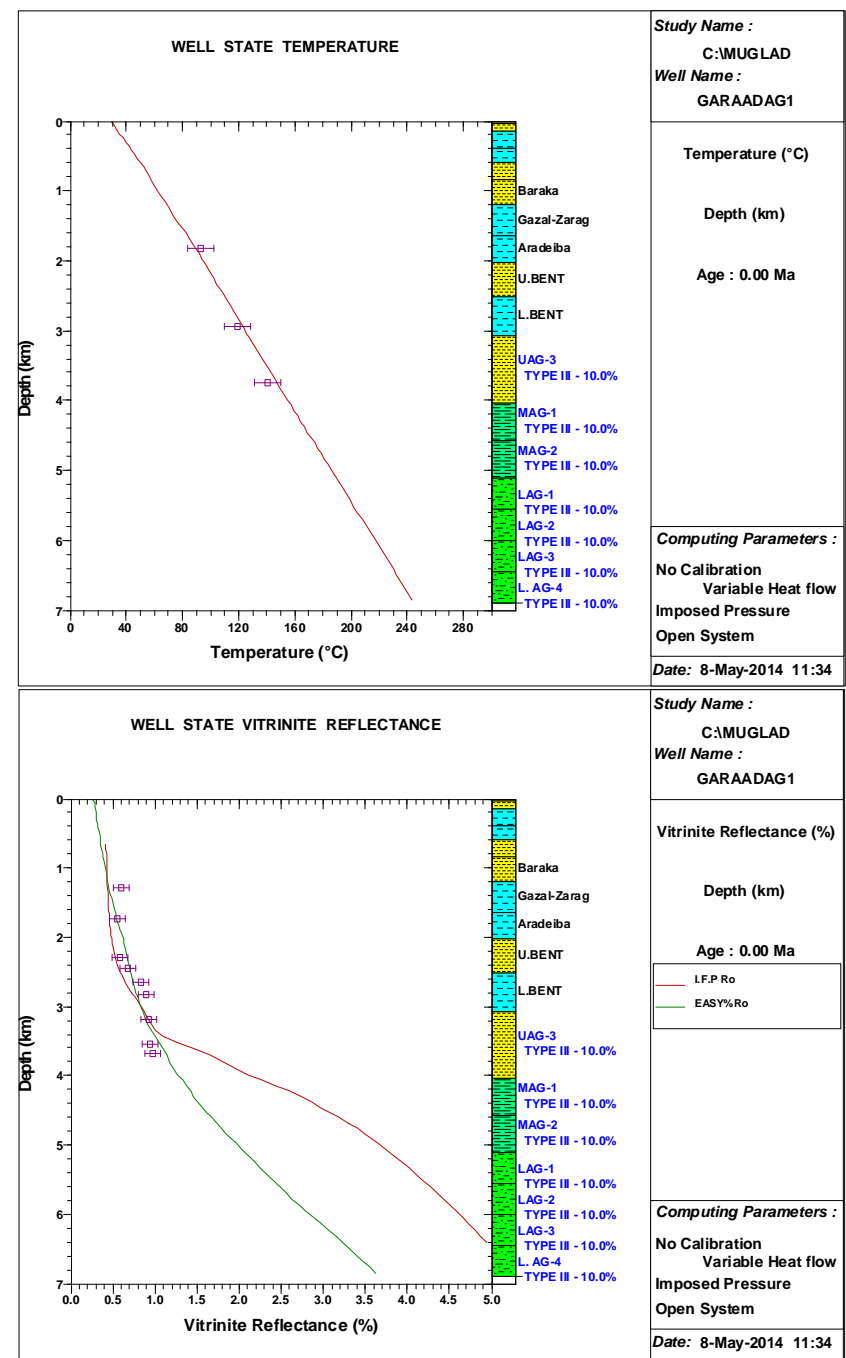

Figures 9 \& 10: Calibrated 1D models for Garad AG-1 well with real temperature and Vitrinite Reflectance data.

The present day oil window in the studied wells is found to range between 2200 and $3320 \mathrm{~m}$ in Seyal-1 well, 1980 and $3000 \mathrm{~m}$ in Jamouse NW-1, 2200 and $3700 \mathrm{~m}$ in Bamboo AG1 and between 2120 and $3250 \mathrm{~m}$ in Garad AG-1 well. And the expected depths of mixed oil and gas generation are range between 3350 and $4250 \mathrm{~m}, 3000$ and $3930 \mathrm{~m}$, and

\section{Volume 5 Issue 8, August 2016}




\section{International Journal of Science and Research (IJSR) \\ ISSN (Online): 2319-7064}

Index Copernicus Value (2013): 6.14 | Impact Factor (2015): 6.391

between 3250 and $4425 \mathrm{~m}$ in Seyal-1, Jamouse NW-1 and Garad AG-1 wells respectively. The gas window started at the last mentioned depths for the three wells. The penetrated section in Bamboo AG-1 did not enter the mixed zone and the gas window (Figs. 11 to 14 ).

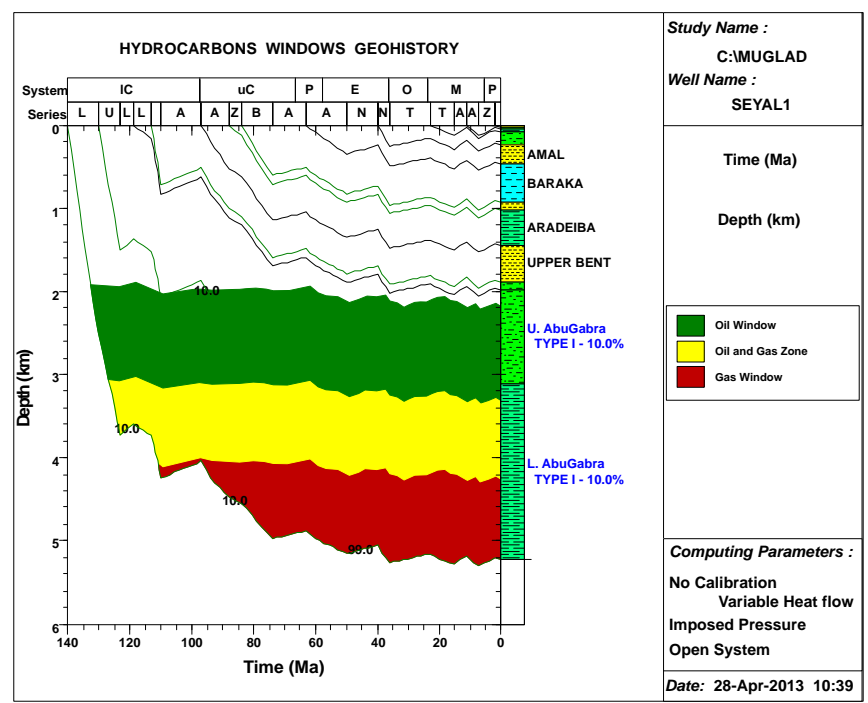

Figure 11: Hydrocarbons windows geohistory of Seyal-1 well

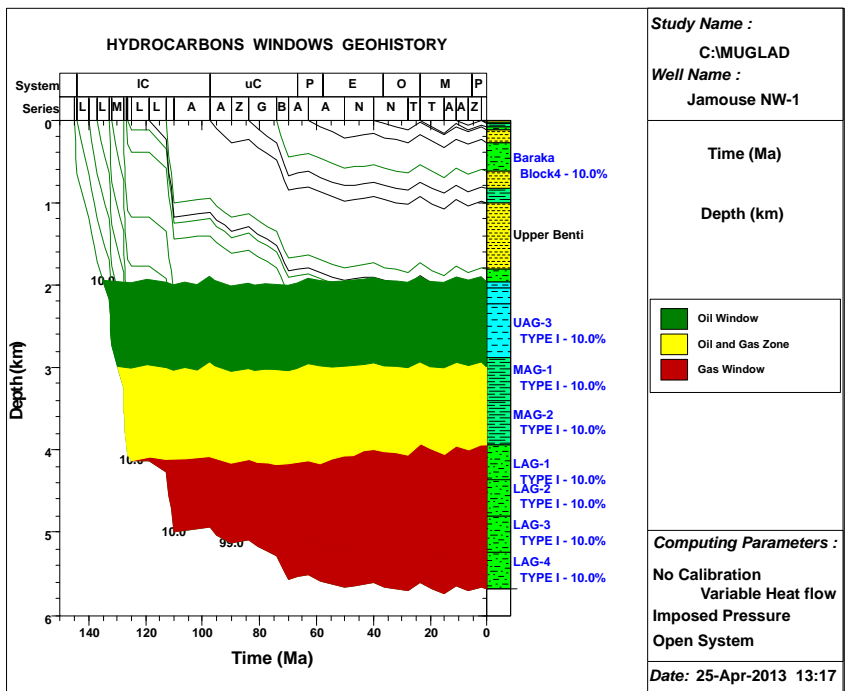

Figure 12: Hydrocarbons windows geohistory of Jamouse NW-1 well

The timing of oil generation in the study area were found to be happened during the Early Cretaceous, whereas the oil generation started at 133, 135, 114.7 and 134.5 Ma in Seyal1, Jamouse NW-1, Bamboo AG-1 and Garad AG-1 wells respectively. These areas reached the peak of oil generation between 127 to $111 \mathrm{Ma}$ in Seyal-1, 130 to $125 \mathrm{Ma}$ in Jamouse NW-1 and between 128.3 to $116 \mathrm{Ma}$ in Garad AG-1 well.

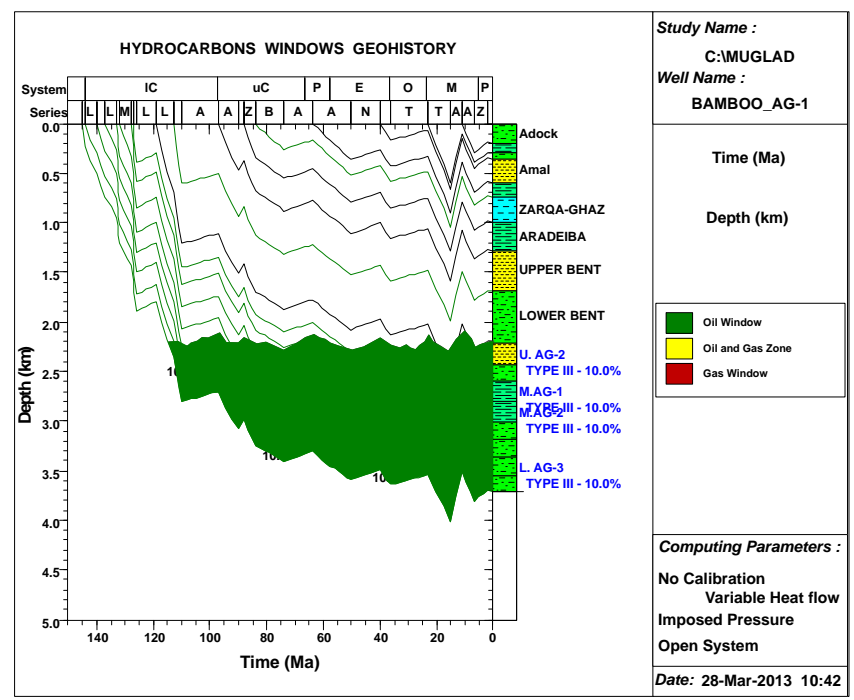

Figure 13: Hydrocarbons windows geohistory of Bamboo AG-1 well.

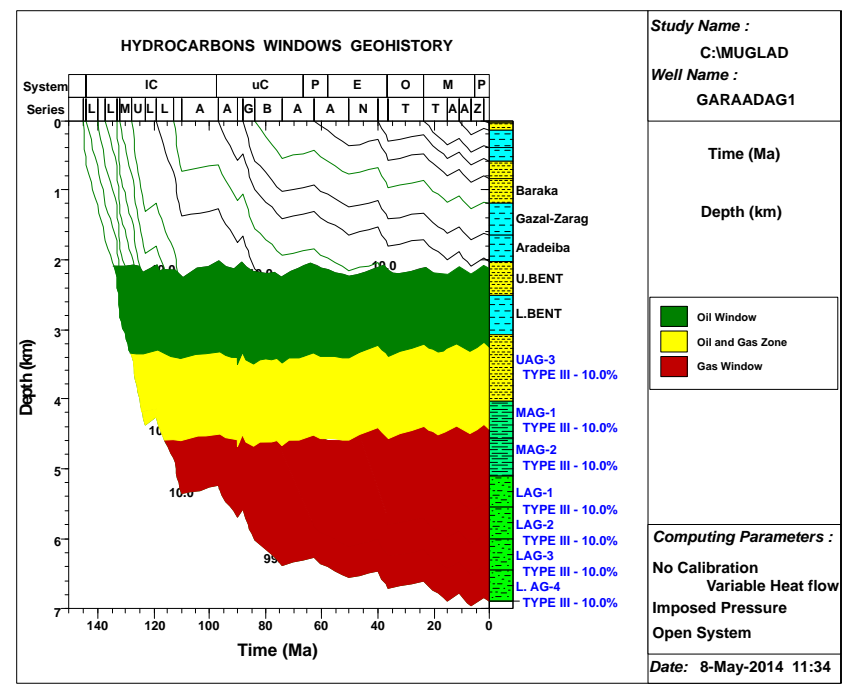

Figure 14: Hydrocarbons windows geohistory of Garad AG1 well.

The expulsion efficiency is a calculation of the amount of generated hydrocarbons that are expelled from the source rock according to percentages assigned to different maturity values (Ro \%) for oil and gas.

The superimposed expulsion windows over the burial history curves for the four wells are displayed in the Figures 15 to 18. The greatest percentages of the oil expulsion in the four studied wells occur within the middle and lower parts of $\mathrm{Abu}$ Gabra Formation. Whereas the ratio of the expulsion in Seyal-1 well exceed more than $80 \%$ in the lower part of Abu Gabra Formation, whereas the expulsion in the middle and lower parts of Abu Gabra in Jamouse NW-1 and Garad AG1 range between 50 to $80 \%$ and 10 to $50 \%$ respectively. The expulsion window in Bamboo AG-1 well indicate that the hydrocarbons in this penetrated section have not expelled yet from the source rock. 


\section{International Journal of Science and Research (IJSR) \\ ISSN (Online): 2319-7064}

Index Copernicus Value (2013): 6.14 | Impact Factor (2015): 6.391

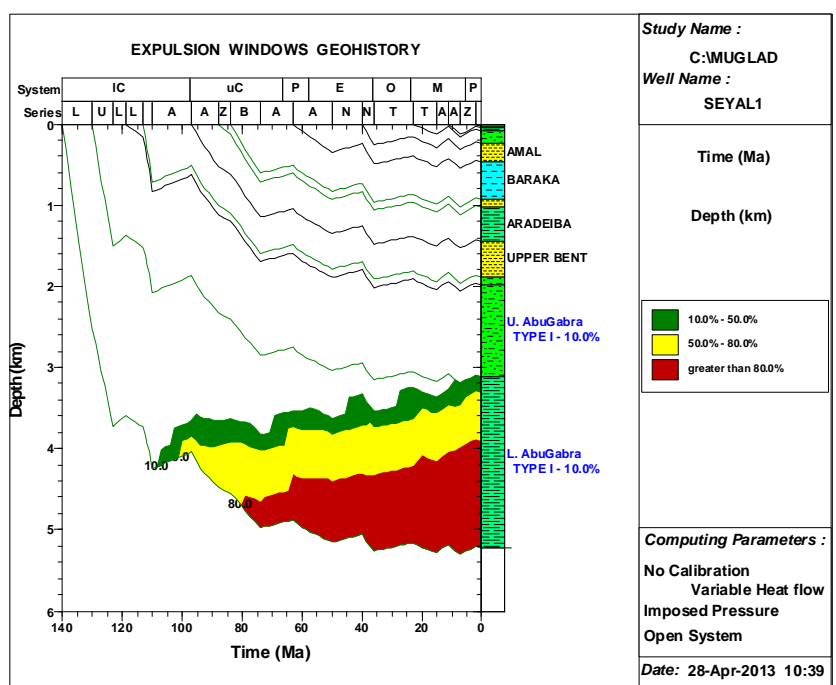

Figure 15: Expulsion windows geohistory of Seyal-1 well.

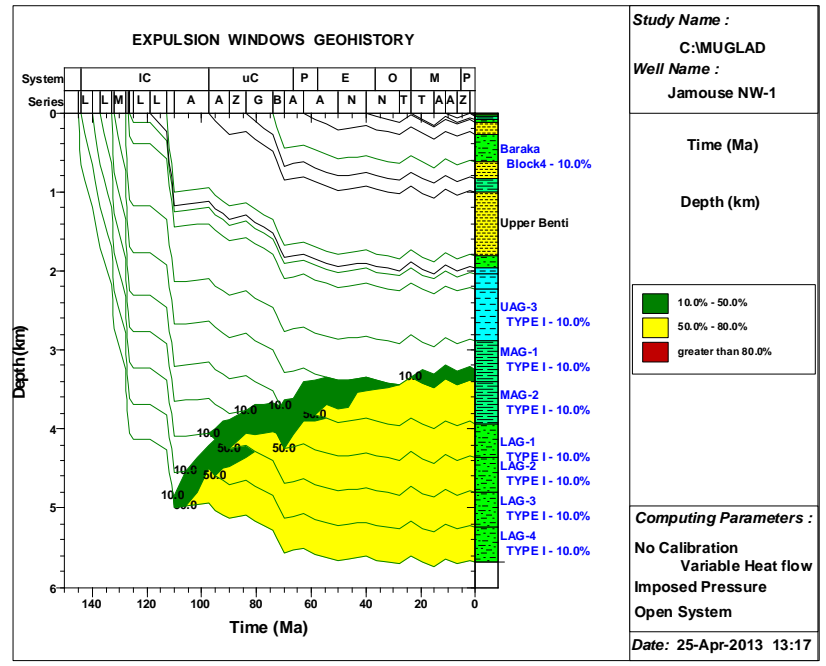

Figure 16: Expulsion windows geohistory of Jamouse NWl1 well.

\section{Conclusion}

The depths of oil generation in the studied wells were obtained from the superimposed maturity data (Ro) on the burial history curves whereas the oil window started at depths more than 2200, 1980 and 2120m in Seyal-1, Jamouse NW-1 and Garad AG-1 wells respectively. The gas window started at 4250,3930 and $4425 \mathrm{~m}$ for the three mentioned wells respectively. The drilled section in Bamboo AG-1 well did not access the mixed zone and the gas window but the penetrated section in Abu Gabra Formation in this well entered the oil generation window at $2200 \mathrm{~m}$.

The burial history curves of the studied wells reflect that, the thermal maturity of the Abu Gabra Formation increase regionally from the northern to the southern parts of the study area owing to the greater subsidence toward the center of the basin.

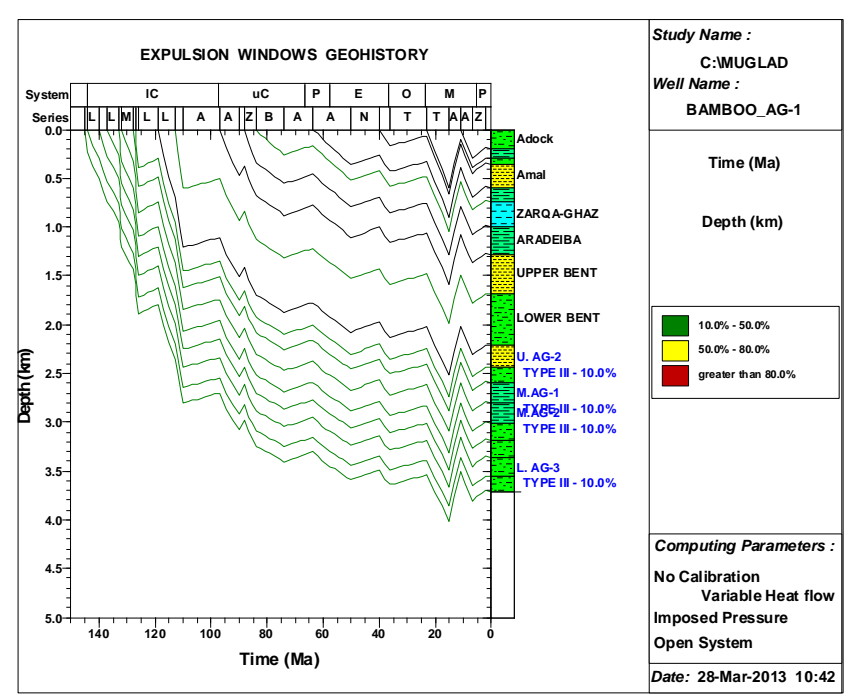

Figure 17: Expulsion windows geohistory of Bamboo AG-1 well.

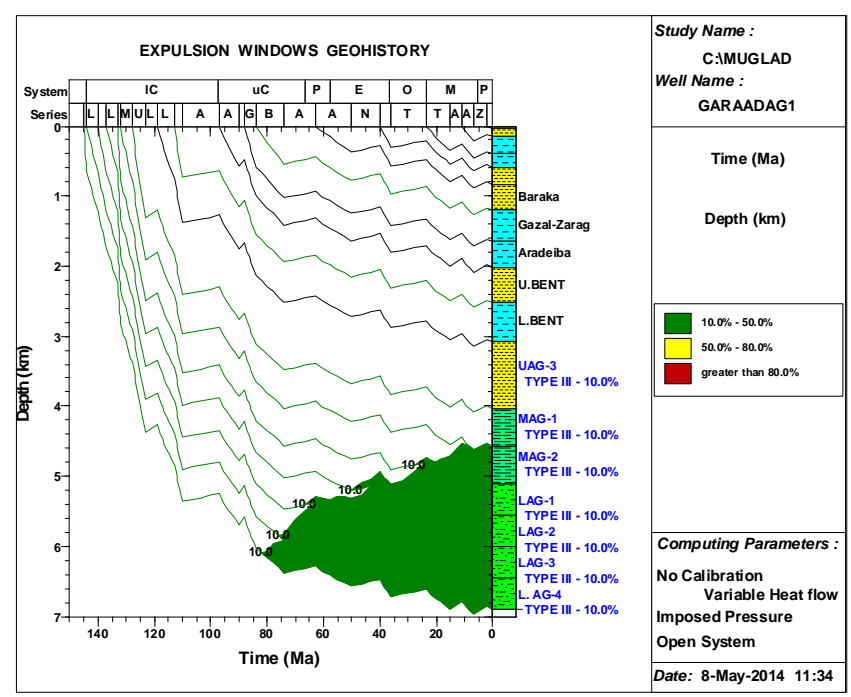

Figure 18: Expulsion windows geohistory of Garad AG-1 well.

The oil generation in Seyal-1, Jamouse NW-1, Bamboo AG1 and Garad AG-1 wells is suggested to have started at 133 Ma, 135 Ma, 114.7 Ma and 134.5 Ma respectively.

The hydrocarbon generation models with superimposed expulsion windows for the modeled wells show the oils were expelled from the middle and lower parts of Abu Gabra Formation. The results of the oil expulsion in the four studied wells indicate that the expulsion decrease from the northern part toward the southern part of the study area.

The oil companies which work in Bamboo field are advised to consider the fact that some of the produced oil in Bamboo field has migrated from other vicinity areas as it has been proved by this research. The reserve estimation and economic studies are recommended to invest the gas accumulations in Heglig field which has been proved by this study. 


\section{Acknowledgment}

Special thanks go to Al-Neelain University, Greater Nile Petroleum Operation Company, Ministry of Petroleum in Sudan for providing the data and the facilities.

\section{References}

[1] Burnham, A.K. and Sweeney, J.J., 1991. Modeling the maturation and migration of petroleum in source and migration processes and evaluation techniques, edited by R.K. Merrill. Treatise of Petroleum Geology Handbook of Petroleum Geology, AAPG Bulletin, 5564.

[2] Ershov, A.V., Brunet, M. F., Nikishin, A.M. Bolotov, S.N., Nazarevich, B.P., \& Korotaev, M.V., 2003. Northern Caucasus basin: thermal history and synthesis of subsidence models. Sedimentary Geology, 156, 95118.

[3] Galushkin, Y.I., Yakovlev, G.E., \& Kuprin, V.F., 2004. Catagenesis evolution and realization of the potential for hydrocarbon generation by organic matter in the Riphean and Vendian deposits of the West Bashkirian basins: numerical modeling. Geochemistry International, 42, 67-76.

[4] Ibrahim, M.M. 2012. Shale gas feasibility in a lacustrine basin Neem-Azraq area, Muglad basin, Sudan. M.Sc. Thesis, Al Neelain University, Khartoum, 151.

[5] Rodriguez, J.F. and Littke, R., 2001. Petroleum generation and accumulation in the Golfo San Jorge Basin, Argentina: a basin modeling study. Marin and Petroleum Geology, 18, 995-1028.

[6] Schull, T. J., 1988. Rift basins of interior Sudan: Petroleum exploration and discovery. AAPG Bulletin, Tulsa, 72, 1128-1142.

[7] Sheng H. \& Middleton, M., 2002. Heat flow and thermal maturity modelling in the Northern Carnarvon Basin, North West Shelf, Australia. Marine and Petroleum Geology, 19, 1073-1088.

[8] Uysal, T., Glikson, M., Golding, S. D. \& Audsley, F., 2000. The thermal history of the Bowen Basin, Queensland, Australia: vitrinite reflectance and clay mineralogy of Late Permian coal measures. Tectonophysics, 323, 105-159.

\section{Author Profile}

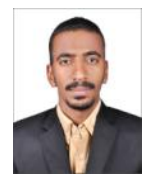

Mohamed Elfatih Z. Gandol is a lecturer at Petroleum Geology department of $\mathrm{Al}$ Neelain University in Khartoum, Sudan. In 2011 he completed B.Sc. (Honours) in Petroleum Geology at the same University. In 2012 he joined Chinese National Logging Corporation (CNLC) as Mudlogging Geologist and in the same year he moved to Spanish Sudanese (SPSU) Mining Company as Senior Exploration Geologist. In 2013 he joined Al Neelain University as Teaching Assistant, in 2014 he received his M.Sc. in Petroleum Geochemistry from it and promoted to his present position. Currently he is doing M.Sc. course in Geophysics at Osmania University, Hyderabad, India. 